\title{
Where do "localphiles" shop? A mixed-methods case study of food-buying habits
}

\author{
Emily McKee* \\ Northern Illinois University
}

Submitted October 30, 2019 / Revised May 5, June 26, July 28, and October 26, 2020 /

Accepted October 26, 2020 / Published online February 11, 2021

Citation: McKee, E. (2021). Where do "localphiles" shop? A mixed-methods case study

of food buying habits. Journal of Agriculture, Food Systems, and Community Development, 10(2),

339-358. https://doi.org/10.5304/jafscd.2021.102.023

Copyright (C) 2021 by the Author. Published by the Lyson Center for Civic Agriculture and Food Systems. Open access under CC-BY license.

\begin{abstract}
Why, with local food's rising popularity, do smallscale farmers report declining sales? This study used a mix of survey and interview methods to examine the priorities and buying habits of food shoppers in one midsized, lower-income metropolitan area of the U.S. Midwest. The study focuses on individual consumers' decision-making because it aims to be useful, in particular, to small-scale farmers and advocates of their participation in local and regional food systems. Among shoppers' stated priorities, the survey found broad support for local food and relatively low competition between price and local origin as purchasing priorities. However, findings also show an attitudebehavior gap, with only a limited increase in tendency among self-defined "local" shoppers to
\end{abstract}

\footnotetext{
* Emily McKee is an associate professor at Northern Illinois University, jointly appointed in the Department of Anthropology and the Institute for the Study of the Environment, Sustainability, and Energy. She can be contacted at: Department of Anthropology, Northern Illinois University; Stevens Building 190; DeKalb, IL 60115 USA; ekmckee@niu.edu
}

purchase from locally oriented venues. As explanation for this attitude-behavior gap, survey and interview data point to differential definitions of "local food" and situational barriers (primarily inconvenience and lack of variety) preventing shoppers from buying local food. One factor offsetting these barriers was past experience growing one's own food. Study findings are used to identify particular avenues for intervention by farmers, eaters, and other food systems builders to broaden access to local food through adjustments to marketing strategies, better alignment of wholesale outlets' practices with the priorities of farmers and eaters, and improved public education about the food system.

\section{Keywords}

Local Food Systems, Shopping Behavior, Shopping Priorities, Attitude-Behavior Gap, Mixed Methods, U.S. Midwest

\section{Funding Disclosure}

Funding for this study was provided by Northern Illinois University's Research and Artistry Grant. 


\section{Introduction}

Direct-to-consumer farms are "taking a nosedive, no question," one lifelong farmer told a group of hopeful newcomers at a beginning farmers' training course in 2016. "This farm is way down in sales this year," he said of his own operation. "We have a good reputation for good food, reliable. But a lot of CSA farms around the country have taken a hit in sales, and farmers markets have taken a hit in sales, too."' The course moderator and fellow farmer chimed in, "it's true; the market is softening. For years, demand was growing. But that's not the case anymore." Indeed, following a boom in direct-market food sales through 2015, farmers across the United States have reported in recent years that sales at farmers markets and through community supported agriculture (CSA) shares have been declining (Angelic Organics Learning Center, n.d.; Bishop, 2018; Huntley, 2016). ${ }^{2}$

Food marketing trends, however, suggest that "local food" still holds strong appeal for shoppers. Industry research firms report growing demand, referring to local food as the "next-gen organic" (Hesterman \& Horan, 2017; Packaged Facts, 2019). Grocery stores across the U.S., including discount stores, offer the organic produce that used to be available only direct from farms, and some stores prominently display "Local" signs next to products. "No one sells local like Walmart," claim advertisements for the retail giant (Philpott, 2012). New types of food sellers, like meal-kit delivery services, similarly tout their localness. "At the heart of Green Chef is supporting local, organic farmland, family farms, and craft economies," claims one purveyor (Green Chef, 2017). Peach Dish promises "local" sourcing, with the tagline, "we know our farmers" (Peach Dish, 2017). While the precise meanings of "local" in these claims may be inconsistent, they do point to widespread enthusiasm for local food.

If shoppers want local food, why are direct- market farmers having such difficulty selling their produce? Working through this contradiction has important implications for our food systems. Local food production can provide resilience to food systems (Zumkehr \& Campbell, 2015). The small, diversified farms so central to direct-market local food provide rural employment and tend to use more ecologically sustainable production strategies than larger farms, while a robust local food economy can strengthen community bonds, particularly in rural areas that have been hollowed out by the past century's industrialization of agriculture (Alonso \& O’Neill, 2011; Bell, 2004; Goldschmidt, 1978; Goodman, DuPuis, \& Goodman, 2012).

However, a celebration of the local without enough reflection regarding what about local production is valuable risks leaving the term open for corporate cooptation and denies important inequalities that manifest at the local level (DuPuis \& Goodman, 2005). For example, popularization of the "locavore" label makes eating local a virtue and normative goal, even as it remains inaccessible for many due to structural inequalities (DeLind, 2011), most notably race and income (Farmer, Menard, \& Edens, 2016; Galt et al., 2017; Lambert-Pennington \& Hicks, 2016).

A growing body of research is attempting to elucidate aspects of the conundrum of high interest in local foods co-occurring with declining directto-consumer farm sales. Many studies focus on better understanding consumer preferences. Quantitative studies predominate in research of local food buying (Feldmann \& Hamm, 2015), with many reporting on generalized preferences or predicted future buying (Bellows, Alcaraz V., \& Hallman, 2010; Carpio \& Isengildina-Massa, 2009; Cholette, Özlük, Özşen, \& Ungson, 2013; Cranfield, Henson, \& Blandon, 2012; Onozaka, Nurse, \& McFadden, 2011). Studies in various geographical locales have found favorable attitudes toward local food among a majority of respond-

\footnotetext{
${ }^{1}$ In CSA farms, people generally buy shares in the harvest by paying a fixed fee at the start of the year, then receive a portion of the harvest throughout the growing season.

${ }^{2}$ U.S. Department of Agriculture (USDA) data (from the Census of Agriculture and the Local Food Marketing Practices Survey) show that farms' direct-to-consumer food sales increased steadily from 1992 to 2015 . Changes in survey questioning structure make it difficult to infer statistical trends from government sources for more recent years, although the 2017 USDA census of agriculture suggests a downturn from the 2015 LFMPS (O’Hara, 2019; see also McFadden, Thomas, \& Onozaka, 2009).
} 
ents, often in a two-thirds to three-quarters majority (Brown, 2003). Because a favorable attitude may not lead to the purchasing of local food, many researchers have used a willingness-to-pay model of assessing the likelihood that people will buy local food, even if it costs more than other options (Carpio \& Isengildina-Massa, 2009; Darby, Batte, Ernst, \& Roe, 2008; Jekanowski, Williams, \& Schiek, 2000). Darby et al. (2008) found that participants' willingness to pay for local was independent of the related variables of product freshness and farm size. They also found that respondents approached at farmers markets were willing to pay higher premiums for local food than those approached at grocery stores.

Such studies benefit from large and diverse samples of the shopping public and provide finetuned analyses of the correlations between preference for local food and various other values and personal characteristics. Many studies have found women, older, and higher-income respondents more likely to express a preference for local food (e.g., Feldmann \& Hamm, 2015). However, there has been some inconsistency in the explanatory power of these demographic factors, with some scholars contending that belief and experience factors explain more of the local preference variation among study participants (Cranfield et al., 2012; Zepeda \& Li, 2006). For example, John Cranfield et al. (2012) found that food buyers who also grew food or prepared meals from scratch stated higher preference for local food than other study participants. Cheryl Brown's (2003) preferences survey found that in households in which food buyers had been raised on a farm or were currently involved in an environmentalist group, respondents stated a higher willingness to pay price premiums for local food.

However, individuals' stated preferences and actual behaviors do not always correspond (Kemp, Insch, Holdsworth, \& Knight, 2010). A great deal can mediate between individuals' willingness and what they actually buy. More thorough understanding of local food participation requires attention to abilities and obstacles.

Ethnographic studies illuminate the meanings of shopping behaviors, showing that in addition to provisioning, shoppers also build social relationships and exhibit particular identities (Miller, 1998). Although qualitative methods have been much less commonly used than quantitative methods in local food buying research, they have helped to clarify the benefits and drawbacks that different people see in local food (Autio, Collins, Wahlen, \& Anttila, 2013; Hinrichs, 2003; Ostrom, 2006). One key finding is the situational nature of such understandings: "local," a short and seemingly straightforward term, is semantically slippery, carrying various connotations and sometimes linked to contradictory political aims (Hinrichs, 2003; Ostrom, 2006; Winter, 2003). This makes it important for studies of local food-buying practices to investigate what "local food" means to a given study's participants. If people's preference for local food is based primarily on perceptions of freshness and responsible production, their food dollars could be more easily captured by nonlocal producers and wholesalers than if the preference is truly based on the place of production (Darby et al., 2008; Ostrom, 2006).

The present study addresses a part of this larger conundrum by asking the primary question: Where do people who state a preference for local food actually obtain their food? It also answers subsidiary questions: Do buyers with different stated preference levels for local food shop in discernibly different ways, and what accounts for any gaps between stated preferences and behaviors? This research takes a case study approach in one midsized metropolitan area of the U.S. Midwest and complements existing literature on local food buying through three methodological elements.

First, this study probes participants' past food buying. This focus on real-world behaviors complements existing research on consumer preferences and intentions to buy local food. The reporting of past behaviors offers a useful method of ground-truthing, but has not yet been as widely utilized (Dukeshire, Masakure, Mendoza, Holmes, \& Murray, 2015; Zepeda \& $\mathrm{Li}$, 2006).

Second, many existing studies of local foodbuying habits focus on one kind of venue, such as 
farmers markets (Alonso \& O’Neill, 2011; Conner, Colasanti, Ross, \& Smalley, 2010; Dodds et al., 2014; Farmer et al., 2016) or, less commonly, grocery stores (Colloredo-Mansfeld et al., 2014). This study examines how shoppers behave across venue types, examining how they weigh multiple priorities to choose venues and determine how to spend their money at those venues. This is significant because farmers want to know where they are most likely to find customers who prioritize buying local food.

Third, this study combines quantitative data on reported food-buying behaviors with qualitative consideration of shoppers' reasons for these behaviors. This mixed-methods approach provides advocates of local food systems with an important window into food buyers' decision-making. It illuminates not only shifts in shopping behaviors over time, but also the decision-making behind attitudebehavior gaps, the differences noted by many researchers between study participants' stated intentions and their actual purchasing behaviors (Feldmann \& Hamm, 2015). In this study, interviews probed the trends revealed by the survey results to allow for the inferring of causal lines between the many "contextual factors" left vague by quantitative studies (Feldmann \& Hamm, 2015). In addition, observations and hypotheses suggested by interview responses, such as the reported necessity of frequenting many discrete venues to obtain one's food from local sources (see below), provided the impetus to run additional quantitative analyses.

The study's locale, Rockford, Illinois, is notable for its location and demographic characteristics. The U.S. Midwest is widely understood as an agricultural heartland, but local food sales have been much less prominent here than in the Northeast and West Coast (Low \& Vogel, 2011; McIlvaineNewsad, Merrett, Maakestad, \& McLaughlin, 2008; Zepeda \& Li, 2006). Using this mixed-methods case study as part of a broader comparative approach to examining food preferences and shopping behaviors in this region, and other areas where farmland abuts dense metropolitan areas, can clarify avenues for increasing the trade of locally produced food.

\section{Methodology}

\section{Case Characteristics}

Rockford lies in northern Illinois, approximately 90 miles $(145 \mathrm{~km})$ northwest of Chicago and 70 miles $(113 \mathrm{~km})$ south of Madison, Wisconsin. At the time of data collection (2017), Rockford city had an estimated population of 147,000 , while the greater Rockford metropolitan area comprised approximately 338,000 (U.S. Census Bureau, 2018). The Rockford area's racial makeup was on par with Midwest regional averages, with a majority of White residents $(80 \%)$ that was much larger than the metropolitan area of Chicago (49\%), but lower than the Madison metropolitan area (86\%). The next largest group reported in Rockford is African Americans (11\%).

Like other Midwestern Rust Belt cities, Rockford flourished around a manufacturing base that has since eroded. The area struggles with high unemployment and depopulation of the city center. Recent efforts to revive the city's social life and employment have included renovating public buildings and making pedestrian-friendly streets, as well as establishing farmers markets, foodfocused summer festivals, and support for new food businesses. Still, the Rockford metro area has a higher proportion of residents in lower income brackets than other northern Midwest metropolitan regions. Unemployment hovers 1 to 2 percentage points higher than Midwest regional averages; residents have lower educational attainment; and food stamp usage is also higher, at $16.9 \%$, compared to $12.9 \%$ for the larger Midwest (StatisticalAtlas.com, 2018). As a lower-income metropolitan region, Rockford is an ideal case study for those interested in economically diversifying the local food movement.

Rockford's proximity to Chicago, Illinois, and Madison, Wisconsin, also likely influences its local food system. Many farms in the greater Rockford area serve the vibrant regional food networks of these larger cities. Each metropolitan area sustains more than a dozen weekly farmers markets during the growing season and has a lively farm-to-table restaurant scene. Madison, in particular, is known as a "foodie" town. Though it is ten times smaller than Chicago, Madison area residents buy approxi- 
mately the same number of CSA shares as Chicago area residents. ${ }^{3}$

\section{Data Collection}

To investigate the importance of local origin compared to other factors in shoppers' food-buying preferences and practices, the principal investigator and two student assistants combined surveys and qualitative interviews. A targeted sample of foodbuying venues was identified across a six-category venue typology: on-farm sales, farmers markets, specialty grocers focusing on natural and local foods, and other grocers (of three sizes: small independent, regional chain, and large chain). Permission to survey shoppers was obtained from 19 venues: three on-farm sales sites, five farmers markets, two specialty grocers, three small independent grocers, four regional grocers, and two large chain grocers.

Researchers stood by the entrance of each venue and invited individuals to participate in the survey. Potential participants were told that the survey addressed shopping habits, without specific reference to local food, to avoid selection bias, and were informed of the cash prize drawing incentive. The written survey questionnaire was kept short to increase response rates. First respondents were asked to list venues from which they buy food and then rank the venues in terms of their average yearly spending in each location. Next, the survey asked respondents about their attitudes toward localness compared to other factors, using the following written prompt: "Many factors influence food purchasing decisions. In relation to the other factors that matter, is it important to you to purchase
Table 1. Study Sample

\begin{tabular}{lccc}
\hline & Venues in study & $\begin{array}{c}\text { Total participants } \\
\text { from venue type }\end{array}$ & $\begin{array}{c}\text { Mean number of } \\
\text { participants per venue }\end{array}$ \\
\hline On-farm & 3 & 40 & 13 \\
Farmers markets & 5 & 85 & 17 \\
Local-natural grocers & 2 & 28 & 14 \\
Other independent grocers & 3 & 42 & 14 \\
Regional grocers & 4 & 65 & 16 \\
Large chain stores & 2 & 22 & 11 \\
\hline All venues & 19 & 282 & 15 \\
\hline
\end{tabular}

\footnotetext{
${ }^{3}$ Personal communication with a CSA farmers' coalition member (August 1,2016) and an administrator of an Illinois local food advocacy nonprofit organization (September 22, 2016).

${ }^{4}$ Cranfield et al. (2012) found that growing one's own food was positively correlated with the intention to buy local. The present study probes this correlation in relation to actual buying behavior, as opposed to intention.
}

locally raised food? (Circle the one that applies to you.)." A valence scale gave respondents the option to choose [1] "not important," [2] "less important," [3] "equal among factors," [4] "higher priority," or [5] "highest priority." For those not responding with "highest priority," the survey asked respondents to list and rank up to two other factors more important to them than "locally raised." It also asked them to report any food they raised themselves and the proportion of their yearly diet that this constituted. ${ }^{4}$ This ordering of questions, asking respondents to describe shopping behavior before reporting shopping preferences, aimed to avoid priming respondents to over-report venues oriented toward local food in order to align their ideals and actions. A total of 282 surveys were completed across all venues (Table 1 ).

Researchers inquired about each respondent's willingness to engage in a follow-up interview and provide contact information. The principal investigator conducted follow-up interviews by phone with 20 participants. Purposive sampling of interviewees (1) focused on those reporting a high localfood priority ( $80 \%$ ranked it 4 or 5 on the 5 -point scale) and (2) included respondents contacted at all six venue types (two from on-farm sites, seven from farmers markets, two from local/natural grocers, two from independent grocers, five from regional grocers, and two from large chain grocers). Open-ended interviews lasted 20 to 30 minutes, gathering further information about respondents' 
buying priorities, their experiences in and motivations for raising their own food (if any), their attraction to certain food venues, why they do not buy locally produced food when they wish to (include their perception of obstacles), their perceptions of local farms, and their experiences with and perceptions of CSA memberships and maildelivered meal-kit services.

\section{Data Analysis}

Descriptive statistics were tabulated regarding the prevalence of local food versus other volunteered priorities, the shopping locations reported, and the rankings of these venues. Survey participants were placed along a $1-5$ scale based upon their stated local-food preference. To aid in the identification of trends, a binary grouping was formed, with those participants who ranked buying local food as highest or higher priority ( 4 or 5 on the survey scale) grouped as self-defined "local" shoppers, and those ranking localness as equal among factors or lower (1-3) grouped as "nonlocal” shoppers.

The researchers examined each reported food sales venue to determine the geographical scale of its food sourcing and sales, then placed them within the six venue types. These six types were used for descriptive analysis. To examine correlations between stated local preference and shopping behavior, the venues were coarsely grouped as "locally oriented" or "nonlocally oriented." Locally oriented food venues are direct-marketing venues (including on-farm sales, online order-and-delivery direct from farms, and farmers markets) and stores that identify as "local" or "natural" foods stores and source a substantial portion of their foods locally. In contrast, other grocery stores (independent, regional chain, and large chain) were considered to be nonlocally oriented. ${ }^{5}$

Statistical tests were then run to examine initial study hypotheses. This included a one-way ANOVA to examine whether those surveyed at more locally oriented food venues matched this behavior with higher stated preferences for local food, as well as a chi-squared test to determine whether self-described local shoppers were more likely to report spending their largest share of food dollars at a locally oriented venue than were nonlocal shoppers.

Deductive coding of interviews, guided by the main interview topics, identified trends in participants' responses as a group and explored variation between self-described local and nonlocal shoppers. These trends were used to understand shoppers' definitions of "local food" and their perceptions of their own stated priorities and any deviation of their shopping behaviors from those priorities, including through accounts of evolving or suddenly shifting food-buying priorities. This analysis also prompted further statistical analysis; complaints about the dispersed nature of local food shopping led to the testing of whether local shoppers buy food from a greater number of stores each year than do nonlocal shoppers ( $t$-test).

\section{Findings and Discussion}

\section{Comparative Interest in Local Food and Other Buying Priorities}

Of the 282 respondents who answered the prompt, buying locally raised food was the highest priority for $21 \%$ (60 respondents), higher priority for 38\% (107), equal among factors for $29 \%(82)$, less important than other factors for $6 \%$ (18), and not important for $5 \%(15) .^{6}$ This produced a coarser grouping of $59 \%$ (167) self-identified local shoppers and $41 \%$ (115) nonlocal shoppers. These interest levels are in line with McFadden et al. (2009), who also found very few respondents professing little or no interest in local food $(7 \%)$ and an overall skewing toward moderate and high interest. However, the proportion of respondents favoring local food in this Rockford sample was in the lower range of the percentages reported in the studies reviewed by Brown (2003).

For respondents who did not rank buying locally produced food as their highest priority, the

\footnotetext{
${ }^{5}$ Large and regional chains in the Rockford area rarely marketed local foods at the time of data collection, making such categorization feasible.

${ }^{6}$ These numbers include two respondents who reported food-buying priorities, but did not report any shopping venue information and are therefore not in the total number of surveys cited above.
} 
most frequently offered priorities more important than localness were price and freshness. While each of these two factors was the highest priority for approximately the same number of respondents (47 cited price and 46 cited freshness), price was far more frequently reported as a second priority (40 cited price versus 14 citing freshness), suggesting that price was somewhat more important to shoppers overall than was freshness. While most factors do not exhibit any clear relationship with different levels of preference for local food, price and convenience are somewhat anomalous, as their frequency rises among shoppers with lower local food preference. Prioritization of freshness was consistent across local priority groups. Together, local food, price, and freshness were the highest priorities for $55 \%$ of respondents. The relatively high agreement about these top three factors is notable because "local" was the only potential buying priority identified by the survey. Other factors were independently offered by respondents.

Beyond these top three factors, other stated priorities were diverse and far less frequently noted (Table 2). Forty-two respondents reported prioritizing particular growing practices over local production (most often specifying "organic," but also noting "no chemicals," "no pesticides," "no GMOs used," or "grassfed") and 38 respondents prioritized "quality." It is notable that a significant number of respondents (22) differentiated "support for local farmers" or "support the local economy" from locally produced food, making this the fifth most cited set of factors. "Convenience" and "store location" may be overlapping categories, in which case they would have a total frequency just lower than "quality."

\section{Defining Local Food}

Survey data appear to show that local food is indeed a high priority for Rockford-area food buyers. However, like participants of other studies, Rockford respondents did not share a common definition of local (Hinrichs, 2003; Ostrom, 2006; Winter, 2003). When asked to define local food, most interviewees referred to geographical area, though the size of that area varied widely.

Responses ranged from food grown "within the 20 -mile [32 km] radius of my house" to food from "Illinois and the states kind of around us." In addition to this geographic focus, though, many interviewees defined local food by a range of factors including health, ecological sustainability, economics, and social obligation. Particularly strikingly, some interviewees identified local food not based on where it was grown, but where it was sold. Definitions included, "food from a store that is near your house" and food from "stores under a twenty-minute drive."

As a result of these varied definitions, shoppers may be referring to vastly different concepts when asserting an interest in local food. Some respondents may perceive themselves to be financially supporting local food by spending at a locally owned independent grocery store, for

\section{Table 2. Shoppers' Fresh Food Buying Priorities}

\begin{tabular}{|c|c|c|c|c|c|c|c|c|c|c|c|c|c|c|c|c|c|c|c|c|c|c|c|}
\hline \multirow{3}{*}{$\begin{array}{l}\text { What priority is } \\
\text { "locally produced } \\
\text { food"? }\end{array}$} & \multirow[b]{3}{*}{$n$} & \multicolumn{22}{|c|}{ What other factors are more important? a } \\
\hline & & \multicolumn{2}{|c|}{ Price } & \multicolumn{2}{|c|}{ Fresh } & \multicolumn{2}{|c|}{$\begin{array}{c}\text { Growing } \\
\text { Practices }\end{array}$} & \multicolumn{2}{|c|}{ Quality } & \multicolumn{2}{|c|}{$\begin{array}{l}\text { Support } \\
\text { Farmers/ } \\
\text { Local Econ. }\end{array}$} & \multicolumn{2}{|c|}{$\begin{array}{l}\text { Store } \\
\text { location }\end{array}$} & \multicolumn{2}{|c|}{$\begin{array}{l}\text { Conven- } \\
\text { ience }\end{array}$} & \multicolumn{2}{|c|}{$\begin{array}{l}\text { Variety/ } \\
\text { Availability }\end{array}$} & \multicolumn{2}{|c|}{$\begin{array}{l}\text { U.S. } \\
\text { Grown }\end{array}$} & \multicolumn{2}{|c|}{ Other } & \multicolumn{2}{|c|}{ No answer } \\
\hline & & \# & $\%$ & \# & $\%$ & $\#$ & $\%$ & \# & $\%$ & \# & $\%$ & \# & $\%$ & \# & $\%$ & \# & $\%$ & \# & $\%$ & \# & $\%$ & \# & $\%$ \\
\hline 5, Highest & 60 & \multicolumn{2}{|c|}{$\mathrm{N} / \mathrm{A}$} & \multicolumn{2}{|c|}{$\mathrm{N} / \mathrm{A}$} & \multicolumn{2}{|c|}{ N/A } & \multicolumn{2}{|c|}{$\mathrm{N} / \mathrm{A}$} & \multicolumn{2}{|c|}{$\mathrm{N} / \mathrm{A}$} & \multicolumn{2}{|c|}{$\mathrm{N} / \mathrm{A}$} & \multicolumn{2}{|c|}{ N/A } & \multicolumn{2}{|c|}{$\mathrm{N} / \mathrm{A}$} & \multicolumn{2}{|c|}{$\mathrm{N} / \mathrm{A}$} & \multicolumn{2}{|c|}{ N/A } & \multicolumn{2}{|c|}{$\mathrm{N} / \mathrm{A}$} \\
\hline 4, Higher & 107 & 29 & 27 & 28 & 26 & 33 & 31 & 16 & 15 & 18 & 17 & 5 & 5 & 3 & 3 & 10 & 9 & 2 & 2 & 15 & 14 & 10 & 9 \\
\hline $\begin{array}{l}3 \text {, Equal to } \\
\text { others }\end{array}$ & 82 & 39 & 48 & 24 & 29 & 10 & 12 & 14 & 17 & 4 & 5 & 9 & 11 & 6 & 7 & 3 & 4 & 2 & 2 & 4 & 5 & 12 & 15 \\
\hline 2, Lower & 18 & 8 & 44 & 3 & 17 & 2 & 11 & 6 & 33 & & & & & 3 & 17 & 2 & 11 & & & 4 & 22 & 1 & 6 \\
\hline 1 , Not a priority & 15 & 11 & 73 & 5 & 33 & 2 & 13 & 2 & 13 & & & 2 & 13 & 3 & 20 & & & & & 1 & 7 & 1 & 7 \\
\hline Total & 282 & 87 & 31 & 60 & 21 & 42 & 15 & 38 & 13 & 22 & 8 & 16 & 6 & 15 & 5 & 15 & 5 & 4 & 1 & 24 & 9 & 24 & 9 \\
\hline
\end{tabular}

a Respondents were allowed to cite up to two other factors more important than local origin.

${ }^{b}$ Examples of growing practices are organic, no chemicals, no GMOs, grassfed 
example, even if the produce sold there was grown overseas. These different definitions of local food may help to explain why some respondents expressed only moderate prioritization of local food, but high prioritization of supporting the local economy (see Table 2).

\section{Reasons for Prioritizing Local Food}

When interviewees who reported prioritizing local food were asked about its benefits, they offered a range of responses, often describing these benefits as synergistic with other shopping priorities. Surveys asked participants to report factors that were more important than local production, but interviewees made clear that these factors existed in a "both/and" relationship as often as in an "either/ or" relationship. For example, more than half of interviewees referred to the freshness of local food, with some explaining that this leads to better flavor and others asserting that food consumed more quickly after harvest contains more nutrients. Some shoppers believed local produce is also more likely to be grown in environmentally sustainable ways and with few harmful chemicals. As one man who had reported a local priority of 4 stated, "It's kind of a trust factor. I think the local people will be more concerned with offering a good product, and maybe they have more interest in protecting the environment, using less pesticides, that kind of thing." These people appreciated being able to "look someone in the eye and ask them" about the food they purchased. Even when faced with a hypothetical choice between a local, nonorganic product and a product labeled as organic in a grocery store, this preference for personal vouching led some to prioritize local. "I would still trust the farmers markets' food more than I would trust a grocery store's food, I think," reasoned one interviewee.

However, not all respondents trusted word-ofmouth assurances. Interviewees who expected more institutionalized verification of growing practices saw localness and low-chemical food as somewhat contradictory priorities. Noting the lack of organic certification among farmers market and roadside vendors, some people felt the need to choose between either buying certified organic produce from stores or buying local food. When asked how they would decide in such a case, the bottom line for many respondents was the impact of food on their bodies. "At this point," explained one shopper who had listed "quality" as his highest priority, "I would probably go with the organic. You know, everything else being equal-price, looks, all that stuff-I would go with what is healthier to go into my body."

One priority that showed particularly strong consensus among interviewees was support for local economies, whether understood to be a benefit of buying local or an alternative emphasis. As noted above in Table 2, 8\% of survey respondents cited supporting local farmers or the local economy as a higher priority than buying local food. On the other hand, 14 of the 20 interviewees explained support for local economies as an inherent impact of local food. Some specified wanting "to support local people," those "who are just working hard at making a living." Many explained a desire for more robust local economies with diversity and competition, and those who worked in small businesses themselves identified some "selfinterest" in their support of local food, as they aimed to enhance the buying power of others in their community and be viewed as cooperative community members.

\section{Comparing Preferences and Behaviors}

How do respondents' degrees of stated preference for local food compare with their reported shopping behaviors? Altogether, respondents listed 96 different food venues, which included 46 locally oriented and 50 nonlocally oriented venues. The reported shopping behaviors of those with a higher stated preference for local food differed in some significant ways from other shoppers, but not consistently. Local shoppers were, indeed, more likely than nonlocal shoppers to report a locally oriented venue as the site where they spent the most fresh food dollars (i.e., listed and ranked first in the survey) $(p=0.004)$ (Table 3). Local shoppers were also more likely to cite a locally oriented venue anywhere in their ranking than were nonlocal shoppers $(p=0.004)$.

When these larger categories are broken down, a trend in overall spending is also somewhat evident for shoppers who report different levels of 
Table 3. Participants' Reportings of Local-focused Food Venues

\begin{tabular}{lcc}
\hline & $\begin{array}{c}\text { Ranked locally oriented } \\
\text { venue FIRST }\end{array}$ & $\begin{array}{c}\text { Listed ANY locally } \\
\text { oriented venue }\end{array}$ \\
\hline Local shoppers $(n=164)$ & $34(21 \%)$ & $105(64 \%)$ \\
Nonlocal shoppers $(n=114)$ & $9(8 \%)$ & $56(49 \%)$ \\
\hline & $* p=0.004$ & $* p=0.012$ \\
\hline
\end{tabular}

"less important" than other factors, respectively), and the two categories together constitute no less than $61 \%$ of cited venues for any group (and as high as $81 \%$ for the group viewing localness as "less important"). In addition, local and nonlocal shoppers reported similar

local-food preference. Altogether, respondents across local and nonlocal groups listed 13 on-farm sales venues, 22 farmers markets, 11 natural/local specialty grocers, 15 other independent grocers, 14 regional grocery chains, and 21 large grocery chains. Reported spending at the six venue types was compared for respondents with different local food priority levels. The following pie charts show, first, the proportion of stores in each venue type that shoppers listed within their top two venues; second, the venue types in their overall lists; and third, only the venues they ranked third or lower. Because survey participants listed their shopping places and ranked them according to dollars spent, the first set of pie charts represents the venues where shoppers spent the most money per venue. The final set includes venues where shoppers spent less money.

The charts in Figure 1 show that local shoppers were more likely than nonlocal shoppers to report spending a significant portion of their food dollars at locally oriented venues. Direct-market venues constituted $17 \%$ of top-ranked venues for self-described local shoppers, and just $8 \%$ for nonlocal shoppers (Figure 1). The shifts in shares of direct-market venues listed came primarily at the expense of regional grocers, and to a lesser extent, large chain stores. The proportions of local-natural grocers and other independent grocers were consistent within top-two and lower-ranked listings.

On the other hand, the correspondence between respondents' stated priorities and reported shopping behaviors was only modest. Figure 1 also shows the reliance among all groups of respondents on large and regional grocery chains. Large chains constituted between $32 \%$ and $55 \%$ of venues cited (among respondents for whom local food is the "highest priority" and for whom it is proportions of different venue types within their lower-ranked venues. Both groups were more likely to cite markets with direct purchases from farmers as places where they spent less money than they were to rank them among their high-spending venues. The small size of many locally oriented venues may partially account for this trend, with people spending a smaller portion of their household food dollars at smaller venues. Although a CSA farm often aims to become its members' primary source of produce (and sometimes eggs, dairy, and other products, as well), and many "local" and "natural" food stores strive to become their customers' primary shopping venues, the larger regional and national chain grocery stores remain central for food shoppers who expressed all levels of local priority.

In addition, the food venues at which researchers encountered shoppers did not robustly correspond with their stated local preferences. A oneway ANOVA examining the mean local importance rank for participants contacted at each type of venue found a difference at the $p<0.05$ level $(\mathrm{F}(5,276)=3.06, p=0.01)$. However, the Tukey HSD test showed only two pairings of participants at different venue types to be significantly different: farmers markets and regional chains $(p=0.039)$, and specialty grocers and regional chains $(p=0.046)$ (Figure 2). None of the other pairings of venue types showed significantly different local rankings. In addition, there was no consistent trend, even at a nonsignificant level by which those surveyed at more locally oriented venues reported a higher local food priority. This suggests that characteristics other than a venue's local orientation were more influential in shaping shoppers' buying behaviors.

This lack of correspondence was found despite

\footnotetext{
${ }^{7}$ The mean number of food venues listed per respondent was 3.3, and less than $6 \%$ of respondents listed more than five food venues.
} 
Figure 1. Reported Spending on Fresh Food, with Participants Grouped by Level of Local Food Priority

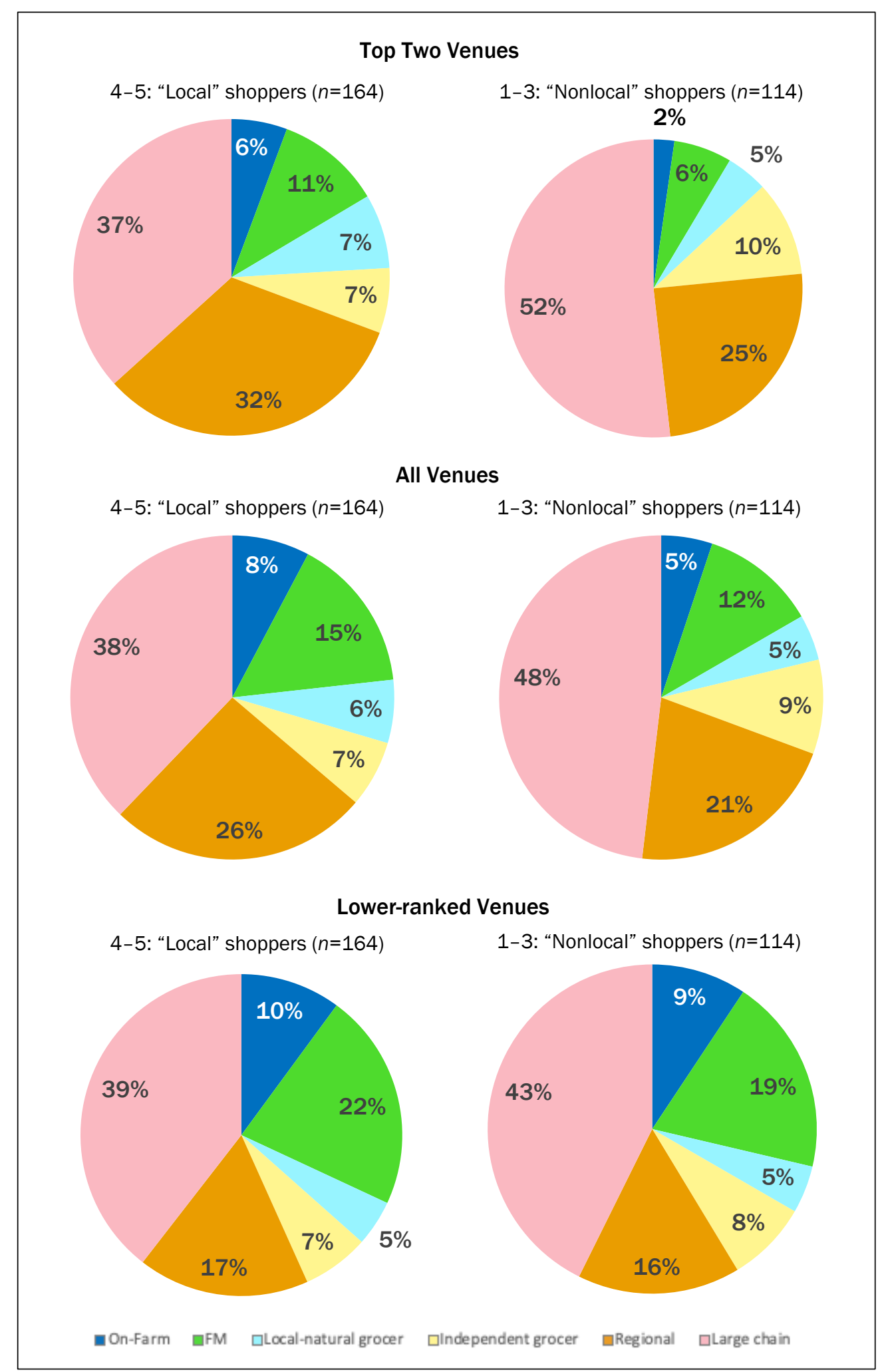


Figure 2. Mean Local Food Importance Rankings, by Survey Venue Type

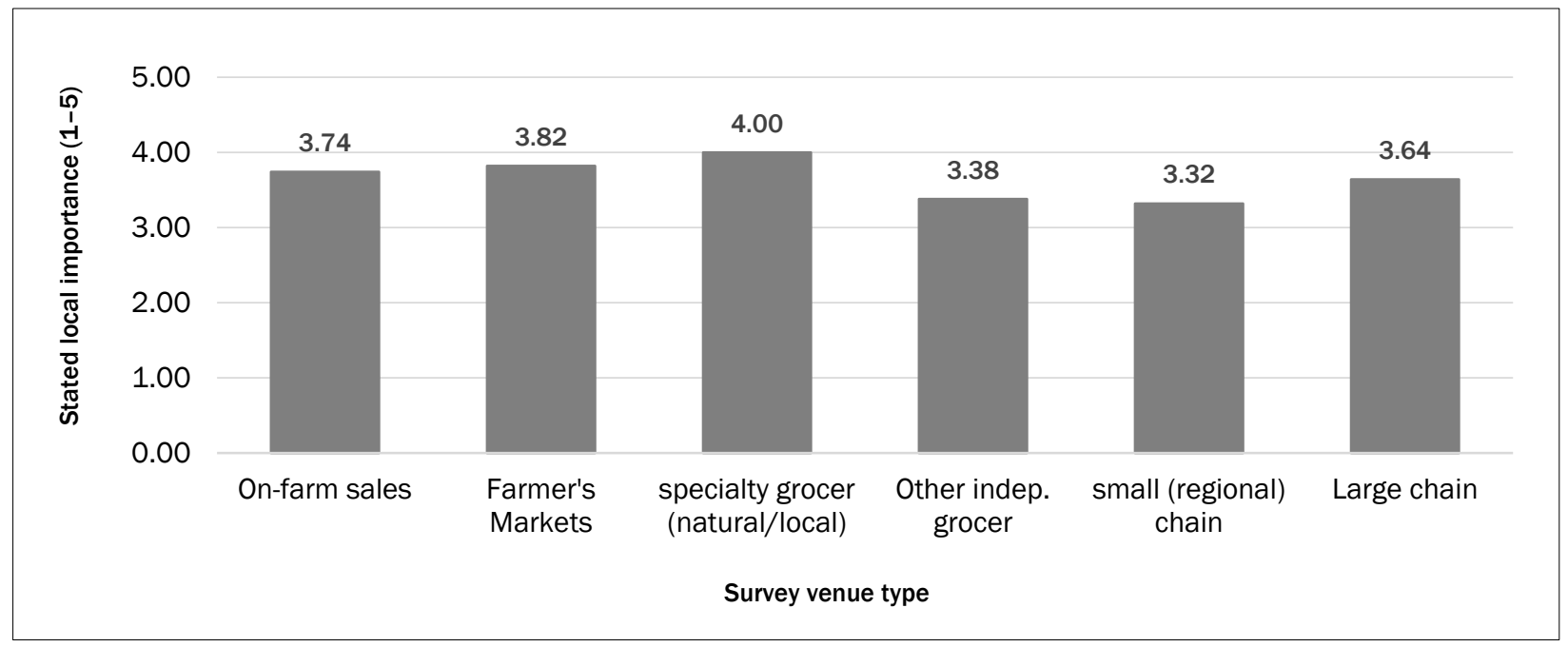

the fact that respondents did show some yearround loyalty to particular types of venues. In other words, the venue type where researchers happened to encounter each respondent did serve as a useful snapshot of that respondent's overall shopping tendencies. In Figure 3, charts show the number of times respondents reported buying food at food venues of different types. Each chart reports the responses of survey participants encountered at a different type of food venue. Respondents encountered at on-farm sales venues reported a larger proportion of on-farm venues among their listed food venues than did respondents encountered at other venue types. This trend held across all venue types except farmers markets. This, too, indicates that people choose shopping venues based on preferences unrelated to the availability of local food, but indirectly tied to venue type. This interpretation is supported by interview data; when asked what drew them to their top-ranked venues, many shoppers noted a favored product that was available only at specific stores, described the aesthetics they preferred (from wide aisles to cosy, small stores), or appreciated the variety of products available at particular venues. ${ }^{8}$

Finally, because one of the most commonly cited obstacles to buying local reported by interviewees was the necessity of visiting many venues to complete their shopping, one could expect that shoppers most committed to local food would visit more venues. Many farmers markets have limited variety, interviewees explained, and even a large farmers market or farm stand does not carry the variety of produce found in a grocery store. Offseason, the challenge grows. As one woman explained: "I know people who go to the farms yearround. But then it's like, maybe I'm gonna have to drive for 40 minutes, and then I'm going to go there and they're not going to have everything I want, or I'm not going to like it." However, as a group, local shoppers did not report visiting a greater variety of different food venues, nor as individuals were they more likely to trek between multiple venues to provision their households compared to nonlocal shoppers (Table 4). Furthermore, the proportion of all venue listings and the diversity of venues reported by each group of shoppers were both in line with their overall representation among survey respondents.

\section{Explaining Behaviors: Why Not Buy Local?}

The pattern that emerges here of self-described local shoppers is of individuals who include one or more direct-market venues and/or locally oriented grocers in their regular shopping circuits. However, such venues constitute a relatively small proportion

\footnotetext{
${ }^{8}$ The farmers market exception may support this interpretation, as the markets serve a dual role of entertainment and shopping, and many survey respondents did not report buying from the farmers markets at which they were encountered.
} 


\section{Figure 3: Frequency at Which Respondents Reported Different Venue Types, Grouped by the Venue Type at Which They were Surveyed}

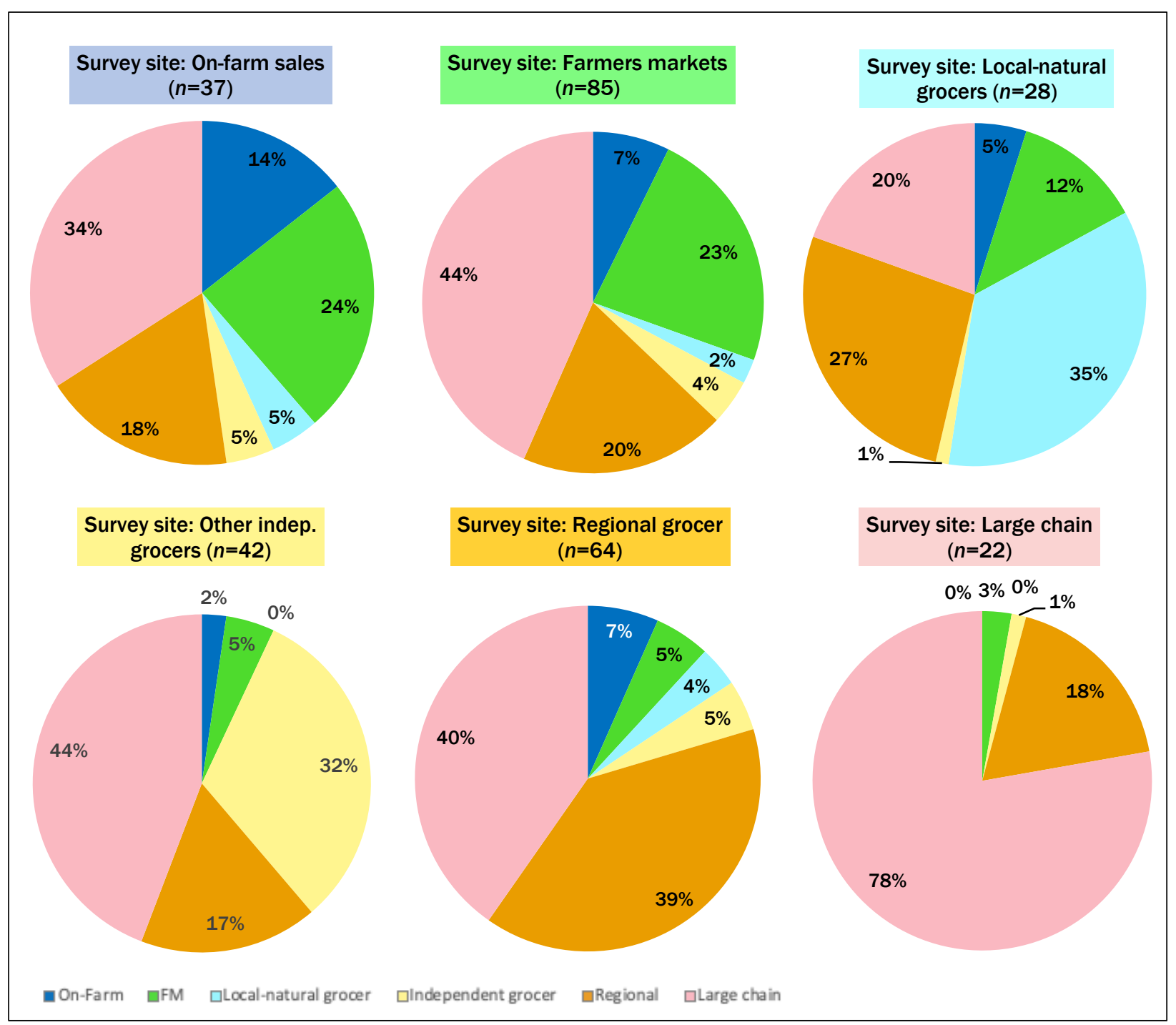

Table 4. Shopping at Multiple Venues

\begin{tabular}{lcccc}
\hline & $\begin{array}{c}\text { Mean \# of venues } \\
\text { reported }\end{array}$ & $\begin{array}{c}\text { \% of survey } \\
\text { respondents }\end{array}$ & $\begin{array}{c}\text { Variety of venues } \\
\text { frequented by group }\end{array}$ & $\begin{array}{c}\text { Discrete venue reportings } \\
\text { by individuals }\end{array}$ \\
\hline Local shoppers $(n=163)$ & 3.39 & $59 \%$ & $82(85 \%)$ & $553(60 \%)$ \\
Nonlocal shoppers $(n=114)$ & 3.27 & $41 \%$ & $65(68 \%)$ & $373(40 \%)$ \\
\hline Total & $p=0.296$ & & Total: 96 & Total: 926 \\
\hline
\end{tabular}

of the food venues they frequent, and large chains and regional grocers remain central for food provisioning. On average, they visit the same number of venues as nonlocal shoppers. Follow-up interviews with survey participants provided insights into three key contextual factors mediating between individuals' priorities and their food-buying behaviors.

Cost was noted as a barrier, but only by five of the 20 interviewees. Despite frequent concerns 
among small-scale farmers that their food is perceived as overly expensive, interviewees did not highlight price as the most significant barrier. In addition, the five respondents who specifically noted having some financial stress were not more likely than the group to highlight price as a barrier. ${ }^{9}$ Even several respondents who mentioned price tempered their comments by acknowledging farmers' justification in charging high prices. As one low-income restaurant worker explained,

Honestly, a lot of times [it's] price. I don't make a ton of money and it's unfortunately hard to justify spending that much more money on produce sometimes. ... I understand it's a fair wage for the amount of effort [the farmers] are putting in and everything, and we don't put enough associated value onto our food a lot of times. We just accepted this idea of cheap food because of farm subsidies and things like that, so we are just detached from it. It's a little bit shocking at times, but at the same time, I'm still poor. Despite the fact I can understand it, I can't necessarily get around it at this time in my life.

Other participants denied that local food is more expensive, asserting that farmers market prices compared favorably with those in grocery stores. "A lot of the stores are more expensive and the produce aren't as fresh," reported one elderly woman on a fixed income who highly prioritized local food. A middle-aged father agreed, saying farmers market prices were "a lot better than your grocery store." Another respondent who initially asserted that farmers market food is "a lot more expensive" then paused and corrected herself: "The vegetables aren't really, but the meat is."

Inconvenience (specified by 11 of 20 interviewees) and a lack of variety (specified by 14 ) were far more important local food barriers for interviewees. As noted above, interviewees across both local and nonlocal groups found it cumbersome to visit multiple venues, sometimes quite far apart, to complete their food shopping. This was the most frequently noted inconvenience. A number of interviewees explicitly wished for more locally produced foods at nearby grocery stores. "I wish that [the farmers] could go to, like, the local market, like Woodman's, and put their local stuff out." In addition, three people spoke of farmers markets' limited hours, often falling during their own work shifts. One final inconvenience mentioned by several people would apply as a challenge for eating fresh food more generally, but may be particularly pronounced if the main local food venues of an area are roadside stands and farmers markets that do minimal washing and prepping of produce: "The pace of life we have," explained one man, "is very fast, and sometimes you don't have enough time for cooking and preparing food."

Interviewees noted a lack of variety both in terms of seasonality and regional limitations. "We don't really do seasonal," reported one mother of young children. Her kids "love watermelon, so we eat watermelons all year round." Most shoppers have become accustomed to accessing any type of food at any time of year. However, most farmers markets close in the fall, farmers can supply only winter and storage crops through other venues, and Rockford's temperate climate is unsuitable for citrus and many other crops that interviewees viewed as mainstays of their diets. Even those striving to eat more seasonally noted limitations such as not being able to afford the necessary time to can and freeze harvest-season bounty. Interviewees also noted a lack of variety, even during harvest season, at their local farmers markets. Reported one recent transplant from Chicago, "it was a lot of the same stuff at the farmers market here in Rockford," unlike the greater variety he had found in Chicago markets.

Two additional concerns drawn from ethnographic work with small-scale farmers (McKee, 2018) were probed with interviewees. First, as farmers have watched the rise of mailorder meal-kit services coinciding with the fall of their own sales, some fear that these fresh food

\footnotetext{
${ }^{9}$ Although quantitative socioeconomic data were not gathered from interviewees, one-quarter mentioned being under financial stress, including one person who relied on Illinois' Supplemental Nutrition Assistance Program, a retired woman on a fixed income, and three individuals with low-income jobs.
} 
vendors are direct competition. However, among this study's sample, meal-kit services were not appealing. In fact, not a single interviewee spoke positively of them, and 13 of the 14 interviewees asked directly about them reported that they would not want to try such a service. Interviewees perceived meal-kit services to be expensive and to offer them little control over their diets.

Second, farmers relying on community supported agriculture (CSA) have seen membership numbers declining and wonder how potential customers view this model of food purchasing. When asked about their perceptions of "CSA," most interviewees (12 of 20) were not familiar with the term. However, when the model was described as a person paying a farmer at the beginning of the season for a share of the harvest and then receiving food deliveries each week, many reported being familiar with the concept. Among those with some exposure to the service, interviewees spoke favorably of CSA's ability to support local farmers and of the great taste of the produce received. They spoke less favorably of the consumers' lack of choice in the produce received, the inconvenience and inflexibility of delivery arrangements, and the food they ended up wasting when receiving large batches of produce weekly or biweekly. Notably, expense was not a common concern preventing participation in CSAs (mentioned by only two interviewees).

In contrast to these barriers, participants' past experience growing food was an influential factor prompting them to purchase local food (a finding supported by Dukeshire et al., 2016, and Cranfield et al., 2012). Repeat-

edly, interviewees reported that growing some of their own produce made them "more aware" —aware of the hard work required to grow food, the seasonality of crops, and the normalcy of irregular shapes and imperfections. This awareness made

\section{Table 5. Participants' Raising of Their Own Food}

\begin{tabular}{|c|c|c|c|c|}
\hline \multirow[b]{2}{*}{ Local importance ranking } & \multirow[b]{2}{*}{$n$} & \multirow{2}{*}{$\begin{array}{l}\text { Percentage of } \\
\text { respondents raising any } \\
\text { of their own food (\%) }\end{array}$} & \multicolumn{2}{|c|}{ Portion of yearly food raised by self } \\
\hline & & & Mean (\%) & Median (\%) \\
\hline Local, 4-5 & 165 & 48 & 15 & 0 \\
\hline 5, Highest & 60 & 42 & 13 & 0 \\
\hline 4, Higher & 105 & 51 & 16 & 20 \\
\hline Nonlocal, 1-3 & 115 & 34 & 8 & 0 \\
\hline 3, Equal to others & 82 & 37 & 10 & 0 \\
\hline 2, Lower & 18 & 39 & 8 & 0 \\
\hline 1, Not a priority & 15 & 13 & 3 & 0 \\
\hline
\end{tabular}

individuals more appreciative of how fresh food should look and taste. As one respondent explained, just growing her own tomatoes for one summer motivated her to seek out local sources: "I sorta realized that the flavor of tomatoes from the store are [sic] completely different from when you get them at the farmers market." Parents said that the experience of growing up with gardens made their kids more open to eating a variety of vegetables, making it easier to eat what was locally in season.

This growing of one's own food did not replace local produce purchasing - only one interviewee estimated growing enough food to offset what she would otherwise buy from local producers-but instead made respondents more appreciative of local food. A few specifically reported greater appreciation for farmers' labor after growing their own food. Stated one shopper who ranked localness as his highest priority, "You do notice the hard work you put in maintaining it, so it doesn't bother you to think you have to pay a little bit more." While interview comments provide evidence of a causal relationship between growing food and prioritizing local food purchases, Table 5 suggests that, among the larger sample of survey participants, both the likelihood of raising one's own food and the portion of yearly food raised were slightly higher for those who more highly prioritize local food.

\section{Implications and Conclusions}

Facing the conundrum of local food popularity and declining direct-market sales, small-scale farmers 
and advocates of local and regional food systems need contextually grounded and nuanced analysis of the multiple, interwoven factors shaping people's food-buying practices (McKee, 2018). This study uses a mixed-methods approach that accounts for shoppers' actual behaviors and their understandings of those behaviors. It does so in the U.S. Midwest, where local food consumption lags far behind the potential of local farm supplies (Zumkehr \& Campbell, 2015), and in one of the nation's lower-income metropolitan regions, the inclusion of which will be critical for establishing food systems that are both economically robust and just. These findings offer insights useful to local food advocates in this geographical region, in particular, and avenues for comparative investigation in other locales.

Several findings, in particular, warrant further discussion. This study found that shoppers desired local food in high proportions, comparable to other studies (Brown, 2003; Feldmann \& Hamm, 2015). However, a large portion of respondents saw local production as nearly balanced with other priorities. Such individuals are unlikely to significantly alter their shopping habits to access local food. Thus, further interventions, either to influence their priorities or make local food easily accessible at their current shopping venues, would likely be necessary to direct their dollars toward local food production.

Price was among the other priorities noted by this sample of shoppers, but not a dominant one. Respondents in other studies have reported price to carry widely variable levels of importance in relation to other factors, from high (Farmer et al., 2016) to moderate (Dukeshire et al., 2015) to statistically insignificant (Tregear \& Ness, 2005). In this study's explicit querying of participants' shopping priorities in comparison with local origin, price and freshness were important (the top two priorities volunteered by respondents), but more people ranked local food as being "most important" than either of these factors. One possible interpretation of the inverse trend between price and localness noted in Table 2 is that those most concerned with price are also least concerned with buying local, and that they are therefore not the shoppers on whom farmers should be focusing their efforts. On the other hand, interview data show many shopping priorities to be synergistic, rather than competing. Although some interviewees described local food as expensive, others asserted the opposite. Overall, the relatively low salience of price as a barrier to buying local food, compared to other factors, is notable given the Rockford area's relatively low-income status. One would expect its salience to be even lower in higher-income areas. These findings suggest that interventions reducing the perceived inconveniences of local food would increase local food purchasing as effectively as price-cutting measures, and could do so without cutting into small-scale farmers' meager profits. Still, further mixedmethods research focused on the issue of price would be useful to work through these somewhat conflicting indicators. The gathering of respondents' demographic and economic data, along with open-ended interviews, could zero in on these price questions: To what extent does price compete with local origin as a shopping priority, for whom is it a barrier, and why?

This study found some correspondence between stated preferences and behaviors, but also a notable attitude-behavior gap (Feldmann \& Hamm, 2015). Locally oriented venues constitute a relatively small portion of shoppers' high-spending food venues over the course of the year, even among those who most highly prioritize localness. And those stating a local priority were not more likely than those without such a priority to trek to many small venues to provision their households. Some of this gap may be explained by the semantic flexibility of the term "local." Some interviewees saw themselves as buying local food if it came from nearby stores (regardless of production locale), and even for those concerned with place of production, a local food range included a 300-mile (483-km) radius reaching to southern Indiana for some, and only a 30 -mile $(48-\mathrm{km})$ radius for others.

However, much more of this attitude-behavior gap can be traced to barriers in the food-buying context, and these barriers point to three potential avenues for intervention: among food producers, eaters, and infrastructure shapers. For farmers, this study offers promising directions for action, but also some cautionary notes. First, people interested 
in local food can be found shopping at all types of venues, but are somewhat more likely than other shoppers to spend at farmers markets and on-farm sites. Second, people producing some of their own food are particularly likely to highly prioritize local food and to appreciate those benefits most often voiced by small- and midscale farmers, such as freshness, nutrition, and the value of farmers' labor. Thus, farmers may find allies and clients by advertising not only at traditional direct-market venues like farmers markets, but also at school and community gardening programs, 4-H and similar youth groups, and even local gardening stores.

For those farmers committed to a CSA model, participants' unfamiliarity with the term "CSA," coupled with their enthusiasm for the approach, suggests that marketing about or re-labeling of the model could attract participants. Respondents' aversion to trekking between multiple venues lends some support to "whole diet CSA" approaches that gather diverse foods into shares (Horton, 2013). However, to the extent that such approaches provide one-stop shopping at the expense of choice, it may be unattractive to shoppers (e.g., raising complaints such as those regarding CSA and meal-kit services).

It should be recognized, though, that farmers are already using a variety of strategies to adapt, from efficiency gains to marketing innovations, despite the strain this puts on slim profit margins and heavy work loads (McKee, 2018). These options for farmer interventions must be complemented by adjustments on the part of eaters, wholesale purchasers, and others involved in the food system. For eaters, the degree to which this study finds shoppers' behaviors diverging from their ideals can be a cautionary reminder as we plan our food buying. The findings also suggest several areas in which eater education could be useful. First, while establishing a unified definition of local food may be neither feasible nor desirable (Ostrom, 2006), the semantic uncertainty found in this study suggests the need for more comprehensive discussions of the term's meanings and more critical evaluation of its use in advertising. Eaters also need to clarify their desires for their food system and understand how their actions contribute to shaping it. For example, while multiple interviewees wished for local food to be available in large grocery stores, none expressed an awareness of the barriers small-scale producers face in marketing to grocery stores. Wholesale distribution reaches plentiful customers but brings much lower prices, and small-scale farmers report a variety of barriers to their accessing these markets, including institutional buyers' expectations for minimum shipment sizes, inflexible timing, and uniform appearance of produce (McKee, 2018). As a result, large farms dominate these marketing channels (Low \& Vogel, 2011). However, grocery stores' policies rely heavily on consumer preference research. If consumers demand locally produced food in terms amenable to small- and midscale production, new opportunities for such farmers may be opened. This requires eaters to attain deeper understanding of the entire food system, from production to consumption and waste generation.

Many of the barriers to local food buying highlighted in this study are not easily solved by individuals. The key inconveniences noted by interviewees-limited local food sales points and the necessity of visiting many such venues - have persisted for at least the past two decades (Brown, 2003; Conner et al., 2010; Wolf, 1997). Novel methods of aggregating produce from multiple farms and consolidating marketing services, such as food hubs, may help local food producers overcome obstacles to wholesale distribution (Barham et al., 2012; Berti \& Mulligan, 2016). However, some studies suggest that these innovations predominantly benefit farms that are already relatively large, and/or focus on few crops (Colasanti et al., 2018; King et al., 2010). These barriers require cooperative action to shift the infrastructures of food production and distribution. Adjusting agricultural subsidies to support not only large-scale grain farming, but also smaller-scale fruit and vegetable production, could enable smaller-scale farmers to compete at wholesale prices and reach customers at the grocery stores where they wish to shop. Alternative distribution schemes, such as farmer cooperatives and food hubs, must also attend to the specific needs and skills of small- and midsize farms (Barham et al., 2012; Blay-Palmer, Landman, Knezevic, \& Hayhurst, 2013). 
Finally, this study points toward several fruitful directions for further research. First, similar studies combining quantitative comparison of shoppers' shopping behaviors in other locales would be useful, particularly those with contrasting socioeconomic profiles and from other U.S. regions. Would the relative importance of price and localness shift dramatically with factors such as average household income? And beyond this small sample of interviewees, which of these priorities are seen as synergistic versus competitive? Second, the relationship found here between experience raising one's own food and degree of local food prioritization warrants exploration. What accounts for this correlation? And does the experience of raising food also close the attitude-behavior gap, leading eaters to buy a greater portion of their food from local sources? Third, while this study focused on household food shoppers in response to the current interests of small-scale farmers in the region, recent trends suggest the need to investigate mediated marketing channels as well. National studies show that farmers' sales to local intermediaries such as grocery stores and schools are rising, even as direct-to-consumer sales decline (Plakias, Demko, \& Katchova, 2019). The USDA has recently begun tracking food sales from farmers to distributors and hubs, but this tracking does not follow through to the final buyer, so little is known about who purchases that food or why. A more thorough understanding of the value chains that constitute local and regional food systems would help farmers find buyers, help eaters understand how their actions affect food systems, and enable local food advocates to build effective infrastructure and education campaigns.

\section{Acknowledgments}

I would like to thank Jessica Farace and Jennifer Rugh for their work as paid research assistants gathering survey data; Nicole LaDue, Anna Klis, Mikaela Rogozen-Soltar, and Kathryn Graber for their feedback on the statistical calculations and writing in manuscript drafts; and three anonymous reviewers at JAFSCD for their thoughtful commentary.

\section{References}

Alonso, A. D., \& O’Neill, M. A. (2011). Investing in the social fabric of rural and urban communities: A comparative study of two Alabama farmers' markets. Community Development, 42(3), 392-409. https://doi.org/10.1080/15575330.2010.546530

Angelic Organics Learning Center. (n.d.). Routes to Farm Summit: Emerging challenges for direct-market farmers. Retrieved from https://routes2farm.org/about/summit/

Autio, M., Collins, R., Wahlen, S., \& Anttila, M. (2013). Consuming nostalgia? The appreciation of authenticity in local food production. International Journal of Consumer Studies, 37(5), 564-568. https://doi.org/10.1111/ijcs.12029

Barham, J., Tropp, D., Enterline, K., Farbman, J., Fisk, J., \& Kiraly, S. (2012). Regional Food Hub Resource Guide. U.S. Department of Agriculture, Agricultural Marketing Service. http://dx.doi.org/10.9752/MS046.04-2012

Bell, M. M. (2004). Farming for us all: Practical agriculture and the cultivation of sustainability. Penn State Press.

Bellows, A. C., Alcaraz V., G., \& Hallman, W. K. (2010). Gender and food, a study of attitudes in the USA towards organic, local, U.S. grown, and GM-free foods. Appetite, 55(3), 540-550. https://doi.org/10.1016/j.appet.2010.09.002

Berti, G., \& Mulligan, C. (2016). Competitiveness of small farms and innovative food supply chains: The role of food hubs in creating sustainable regional and local food systems. Sustainability, 8(7), 616. https://doi.org/10.3390/su8070616

Bishop, K. M. (2018, February). CSA farmer struggles to find ways to boost members' interest, participation. Organic Broadcaster, 26(1), 7-12. Retrieved from https://mosesorganic.org/broadcaster-csa-ideas/

Blay-Palmer, A., Landman, K., Knezevic, I., \& Hayhurst, R. (2013). Constructing resilient, transformative communities through sustainable "food hubs." Local Environment, 18(5), 521-528. https://doi.org/10.1080/13549839.2013.797156

Brown, C. (2003). Consumers' preferences for locally produced food: A study in southeast Missouri. American Journal of Alternative Agriculture, 18(4), 213-224. https://doi.org/10.1079/AJAA200353 
Carpio, C. E., \& Isengildina-Massa, O. (2009). Consumer willingness to pay for locally grown products: The case of South Carolina. Agribusiness, 25(3), 412-426. https://doi.org/10.1002/agr.20210

Cholette, S., Özlük, Ö., Özşen, L., \& Ungson, G. R. (2013). Exploring purchasing preferences: Local and ecologically labelled foods. Journal of Consumer Marketing, 30(7), 563-572. https://doi.org/10.1108/JCM-04-2013-0544

Colasanti, K., Hardy, J., Farbman, J., Pirog, R., Fisk, J., \& Hamm, M. W. (2018). Findings of the 2017 National Food Hub Survey. Michigan State University Center for Regional Food Systems \& The Wallace Center at Winrock International. https://www.canr.msu.edu/resources/2017-food-hub-survey

Colloredo-Mansfeld, R., Tewari, M., Williams, J., Holland, D., Steen, A., \& Wilson, A.-B. (2014). Communities, supermarkets, and local food: Mapping connections and obstacles in food system work in North Carolina. Human Organization, 73(3), 247-257. https://doi.org/10.17730/humo.73.3.d2n4042613u08581

Conner, D., Colasanti, K., Ross, R. B., \& Smalley, S. B. (2010). Locally grown foods and farmers markets: Consumer attitudes and behaviors. Sustainability, 2(3), 742-756. https://doi.org/10.3390/su2030742

Cranfield, J., Henson, S., \& Blandon, J. (2012). The effect of attitudinal and sociodemographic factors on the likelihood of buying locally produced food. Agribusiness, 28(2), 205-221. https://doi.org/10.1002/agr.21291

Darby, K., Batte, M. T., Ernst, S., \& Roe, B. (2008). Decomposing local: A conjoint analysis of locally produced foods. American Journal of Agricultural Economics, 90(2), 476-486. https://doi.org/10.1111/j.1467-8276.2007.01111.x

DeLind, L. B. (2011). Are local food and the local food movement taking us where we want to go? Or are we hitching our wagons to the wrong stars? Agriculture and Human V alues, 28(2), 273-283. https://doi.org/10.1007/s10460-010-9263-0

Dodds, R., Holmes, M., Arunsopha, V., Chin, N., Le, T., Maung, S., \& Shum, M. (2014). Consumer choice and farmers' markets. Journal of Agricultural and Environmental Ethics, 27(3), 397-416. https://doi.org/10.1007/s10806-013-9469-4

Dukeshire, S., Masakure, O., Mendoza, J., Holmes, B., \& Murray, N. (2015). Understanding consumer choices for Ontario produce. Renewable Agriculture and Food Systems, 30(5), 439-449. https://doi.org/10.1017/S1742170514000234

Dukeshire, S., Mendoza, J., Masakure, O., Holmes, B., Rippey, J., \& Henson, S. (2016). Globavores, localfors, and locavores: How Canadians perceive local food. In P. Vaughn (Ed.), Food markets: Consumer perceptions, government regulations and health impacts (pp. 13-44). New York: Nova Science Publishers.

DuPuis, E. M., \& Goodman, D. (2005). Should we go "home" to eat?: Toward a reflexive politics of localism. Journal of Rural Studies, 21(3), 359-371. https://doi.org/10.1016/j.jrurstud.2005.05.011

Farmer, J., Minard, S., \& Edens, C. (2016). Local foods and low-income communities: Location, transportation, and values. Journal of Agriculture, Food Systems, and Community Development, 6(4), 41-53. https://doi.org/10.5304/jafscd.2016.064.009

Feldmann, C., \& Hamm, U. (2015). Consumers' perceptions and preferences for local food: A review. Food Quality and Preference, 40(Part A), 152-164. https://doi.org/10.1016/j.foodqual.2014.09.014

Galt, R. E., Bradley, K., Christensen, L., Fake, C., Munden-Dixon, K., Simpson, N., Surls, R., \& Van Soelen Kim, J. (2017). What difference does income make for Community Supported Agriculture (CSA) members in California? Comparing lower-income and higher-income households. Agriculture and Human Values, 34(2), 435-452. https://doi.org/10.1007/s10460-016-9724-1

Goldschmidt, W. R. (1978). As you sow: Three studies in the social consequences of agribusiness. Allanheld, Osmun.

Goodman, D., DuPuis, E. M., \& Goodman, M. K. (2012). Alternative food networks: Knowledge, practice, and politics. Routledge. https://doi.org/10.4324/9780203804520

Green Chef. (2017). Do you support local, sustainable, and artisanal suppliers? Green Chef Support. https://greenchef.zendesk.com/hc/en-us/articles/207928446-Do-you-support-local-sustainable-and-artisanalsuppliers-

Hesterman, O. B., \& Horan, D. (2017, April 25). The demand for "local" food is growing-Here's why investors should pay attention. Business Insider. https://www.businessinsider.com/the-demand-for-local-food-is-growing-2017-4

Hinrichs, C. C. (2003). The practice and politics of food system localization. Journal of Rural Studies, 19(1), 33-45. https://doi.org/10.1016/S0743-0167(02)00040-2 
Horton, E. C. (2013, September 10). Whole-diet CSAs offer food-and-farm connection. Washington Post. https://www.washingtonpost.com/lifestyle/food/whole-diet-csas-offer-food-and-farmconnection/2013/09/09/c55912c4-1597-11e3-804b-d3a1a3a18f2c story.html

Huntley, S. (2016, August 17 | Reposted 2018, July 11). CSA: We have a problem [Blog post]. Harvie. https://www.harvie.farm/blog/csa-we-have-a-problem/

Jekanowski, M. D., Williams, D. R., \& Schiek, W. A. (2000). Consumers' willingness to purchase locally produced agricultural products: An analysis of an Indiana Survey. Agricultural and Resource Economics Review, 29(1), 43-53. https://doi.org/10.1017/S1068280500001428

Kemp, K., Insch, A., Holdsworth, D. K., \& Knight, J. G. (2010). Food miles: Do UK consumers actually care? Food Policy, 35(6), 504-513. https://doi.org/10.1016/j.foodpol.2010.05.011

King, R. P., Hand, M. S., DiGiacomo, G., Clancy, K., Gomez, M. I., Hardesty, S. D., Lev, L., \& McLaughlin, E. W. (2010). Comparing the structure, size, and performance of local and mainstream food supply chains (Economic Research Report ERR-99). U.S. Department of Agriculture, Economic Research Service. https://www.ers.usda.gov/publications/pub-details/?pubid $=46407$

Lambert-Pennington, K., \& Hicks, K. (2016). Class conscious, color-blind: Examining the dynamics of food access and the justice potential of farmers markets. Culture, Agriculture, Food and Environment, 38(1), 57-66. https://doi.org/10.1111/cuag.12066

Low, S. A., \& Vogel, S. J. (2011). Direct and intermediated marketing of local foods in the United States (Economic Research Report No. 128). USDA ERS. https://www.ers.usda.gov/publications/pub-details/?pubid=44926

McFadden, D. T., Thomas, C., \& Onozaka, Y. (2009). Who are the locavores and where do they shop? An analysis of fresh produce market choices in the United States (Agricultural Marketing Report No. 09-02). Colorado State University, Department of Agricultural and Resource Economics. http://hermes.cde.state.co.us/drupal/islandora/object/co\%3A11304/datastream/OBJ/view

McIlvaine-Newsad, H., Merrett, C. D., Maakestad, W., \& McLaughlin, P. (2008). Slow food lessons in the fast food Midwest. Journal of Rural Social Sciences, 23(1), 72-93. http://journalofruralsocialsciences.org/

McKee, E. (2018). "It's the Amazon world": Small-scale farmers on an entrepreneurial treadmill. Culture, Agriculture, Food and Environment, 40(1), 65-69. https://doi.org/10.1111/cuag.12107

Miller, D. (1998). A theory of shopping. Cornell University Press.

O’Hara, J. (2019, May 28). The 2017 Census of Agriculture and local food trends: What can we say? [Webinar]. National Farm to Institution Metrics Collaborative. https://www.youtube.com/watch?v=GyfnKCq0ZsA

Onozaka, Y., Nurse, G., \& McFadden, D. T. (2011). Defining sustainable food market segments: Do motivations and values vary by shopping locale? American Journal of Agricultural Economics, 93(2), 583-589. https://doi.org/10.1093/ajae/aaq152

Ostrom, M. (2006). Everyday meanings of "local food": Views from home and field. Community Development, 37(1), 6578. https://doi.org/10.1080/15575330609490155

Packaged Facts. (2019, February 6). U.S. food market outlook 2019 [Market research report]. https://www.packagedfacts.com/Food-Outlook-12079368/

Peach Dish. (2017). Peach Dish home page. Meal kits \& groceries from small farmers \& Southern chefs | PeachDish. https://www.peachdish.com/ [No longer an active website]

Philpott, T. (2012). Is Walmart really going organic and local? Mother Jones, March/April. https://www.motherjones.com/environment/2012/03/walmart-groceries-organic-local-food-deserts/

Plakias, Z. T., Demko, I., \& Katchova, A. L. (2019). Direct marketing channel choices among US farmers: Evidence from the Local Food Marketing Practices Survey. Renewable Agriculture and Food Systems, 35(5), 475-489. https://doi.org/10.1017/S1742170519000085

StatisticalAtlas.com. (2018). Statistical Atlas: Overview of the Midwest. The Demographic Statistical Atlas of the United States. Retrieved June 19, 2019, from https://statisticalatlas.com/region/Midwest/Overview

Tregear, A., \& Ness, M. (2005). Discriminant analysis of consumer interest in buying locally produced foods. Journal of Marketing Management, 21(1-2), 19-35. https://doi.org/10.1362/0267257053166811 
U.S. Census Bureau. (2018). American FactFinder [Database]. https://factfinder.census.gov/faces/nav/jsf/pages/index.xhtml [American FactFinder has been decommissioned]

Winter, M. (2003). Embeddedness, the new food economy and defensive localism. Journal of Rural Studies, 19(1), $23-32$. https://doi.org/10.1016/S0743-0167(02)00053-0

Wolf, M. M. (1997). A target consumer profile and positioning for promotion of the direct marketing of fresh produce: A case study. Journal of Food Distribution Research, 28(3), 11-17. https://doi.org/10.22004/ag.econ.27211

Zepeda, L., \& Li, J. (2006). Who buys local food? Journal of Food Distribution Research, 37(3). 1-11. https://doi.org/10.22004/ag.econ.7064

Zumkehr, A., \& Campbell, J. E. (2015). The potential for local croplands to meet US food demand. Frontiers in Ecology and the Environment, 13(5), 244-248. https://doi.org/10.1890/140246 